\title{
Çocukluk Dönemi Yürütücü İşlev Envanteri-Ebeveyn Formu'nun 48-72 Aylık Çocuklara Uyarlanması ve Bazı Değişkenler Açısından Yordanma Gücünün İncelenmesi
}

\author{
DOI: $10.26466 /$ opus. 832602
}

\begin{abstract}
Nuran Tuncer *
*Dr. Öğr Üyesi, Tokat Gaziosmanpaşa Üniversitesi, Eğitim Fakültesi, Tokat/Türkiye E-Posta: nurantuncer72@gmail.com

ORCID: $\quad$ 0000-0002-8748-5084

Öz
\end{abstract}

Bu çalışmanın amacı, 48-72 aylık çocukların çocukluk dönemi yürütücü işlev becerilerinin ebeveyn değerlendirmesine dayalı olarak bazı değişkenler açısından yordanma gücünün incelenmesidir. Çalışmanın örneklemini, geçerlik-güvenilirlik çalışması için 48-72 aylık dönemde çocuğu olan 340 ebeveyn, değişkenler açısından yordanma gücü için ise 349 ebeveyn oluşturmaktadır. Çalışmada veri toplamak için, Kişisel Bilgi Formu ve Çocukluk Dönemi Yürütücü İ̧̧levler Envanteri- Ebeveyn Formu (ÇDYİE) kullanılmıştır. Çocukluk Dönemi Yürütücü İşlevler Envanteri (ÇDYİE) araştırmacı tarafından 48-72 aylık çocuklar için geçerlik-güvenilirlik analizleri yapılarak, çalışmada veri toplama aracı olarak kullanılmıştır. Yapısal eşitlik modeline göre geçerli olduğu kanısına varılan ölçeğin, tüm maddeleri için hesaplanan toplam güvenirlik katsayısı (Cronbach alpha) 88 olarak bulunmuştur. Ölçme aracının geçerli ve güvenilir olduğunun tespit edilmesinin ardından ölçeğin değişkenlere göre değerlendirilmesi sürecine geçilmiştir. Çalışmanın sonunda, çalışmaya katılan ebeveynlerin çocuklarının çocukluk dönemi yürütücü işlevler envanterine göre çocukların doğum strasına göre anlamlı bir farklılğ̆ın olduğu sonucuna ulaşılmıştır. Bu farklılık çalışma belleği boyutunda ilk çocuk ile ortanca ve son çocuk arasında, ilk çocuk lehine anlamlı olduğu saptanmıştır $(p<.01)$. Önleyici Kontrol boyutunda ise ortanca çocuk ile son çocuk arasında ortanca çocuk lehine anlamlı düzeyde bir farklılaşmasının olduğu görülmüştür ( $p<.01)$. Yürütücü işlev becerilerinin toplamında ise ilk çocuk ile son çocuk arasında ilk çocuk lehine anlamlı düzeyde bir farklılığın olduğu belirlenmiştir ( $p<.01)$. Ancak çalışma belleği ve önleyici kontrol becerilerinde cinsiyet, yaş ve kardeş sayısı değiş̧kenlerine göre bir farklilık olmadiğ tespit edilmiştir. Buna göre; okul öncesi öğretmenlerinin çocukların çalışma belleği ve önleyici kontrol becerilerini geliştirmeye ve desteklemeye yönelik sınf stratejilerini kullanabilmeleri için hizmet içi eğitimler aracılı̆̆lyla yetiştirilmesi ve çocukların bu performanslarım artırmayı amaçlayan okul öncesi eğitim programları hazırlanarak uygulanması önerilmiştir.

Anahtar Kelimeler: Okul öncesi eğitim, çocukluk dönemi, yürütücü işlev becerileri, çalışma belleği, önleyici kontrol, ölçek geliştirme 


\title{
The Adaptation of the Parents' Form of the Childhood Executive Functioning Inventory for 48-72 Month Children and the Analysis of Its Predictive Power in Terms of Some Variables
}

\begin{abstract}
The aim of the study is to analyze the childhood executive functions of 48-72 month children on the basis of the parents' assessments in terms of some variables. The sample of the study consists of 340 parents for the validity-reliability study and of 349 parents for the predictive power of the variables.Also, Personal Information Form and Childhood Executive Functioning Inventory (CHEXI) were used for the data collection. The Childhood Executive Functioning Inventory (CHEXI) was used by the researcher as a tool to collect data after its validity-reliability for the 48-72 month children was analyzed. The total reliability coefficient (Cronbach alpha) for all the items in the scale, which was seen to be valid according to the structural equatation model, was found to be .88. After the confirmation of the validity and reliability of the assessment instrument, the evaluation of the scale according to the variables was begun. At the end of the study, it is found out that there is a significant difference depending on the birth order of the children. This difference, between the firstborns, middles and lastborns, is seen to be significant in favour of the firstborns in the working memory $(p<.01)$. As for the inhibitory control dimension, it is seen that there is a significant difference between the middles and lastborns in favour of the middles $(p<.01)$. In the total of the executive function skills, it is concluded that there is a significant difference between the firstborns and lastborns in favour of the firstborns ( $p<.01)$. On the other hand, in the working memory and inhibitory control skills, it is found out that there is not a significant difference in terms of the variables: gender, age and the number of siblings. As a result, it is suggested the preschool teachers be trained through inservice trainings so that they can use classroom strategies to develop and support children's working memory and inhibitory control skills, and the preschool training programmes which aim to increase these performances be prepared and implemented.
\end{abstract}

Keywords: Pre-school education, childhood period, executive function skills, working memory, inhibitory control, scale development 


\section{Giriş}

Yürütücü işlevler, problem çözmeyi, kendi kendini kontrol edebilmeyi ve hedefe yönelik davranışı destekleyen bir grup bilişsel süreci içine alan bir terimdir (Camerota, Willoughby, Kuhn, ve Blair, 2018) ve çalısma belleği, önleyici kontrol (inhibitör control), bilişsel esneklik ve planlama gibi yüksek dereceli bilişsel yetenekler olarak tanımlanan, çevreye, uyarıcılara ve çeşitli durumlara adapte olma, hedef belirleyebilme ve değiştirebilme, plan yapma, sonuçları hesap etme ve tüm bu süreçleri dikkate alarak tepki verebilmeyi ve bu tepkiler sırasında duygularını kontrol edebilme gibi birkaç alt düzey beceriyi de kapsayan, şemsiye bir terim olarak ifade edilmektedir (Baron, 2004, s. 135; Garon, Bryson, ve Smith, 2008; Thorell ve Catale, 2014; Welsh, Nix, Blair, Bierman, ve Nelson, 2010). Yürütücü işlev becerileri yaşamın ilk yirmi yılı boyunca gelişmesine rağmen, bu beceriler için erken çocukluk dönemi en hızlı gelişimsel değişim dönemi olarak tanımlanmıştır (Garon vd., 2008). Bu nedenle, 0-6 yaş dönemini kapsayan okul öncesi çağdaki çocuklarda yürütücü işlev becerilerinin ölçülmesine büyük çaba harcanmıştır. Bu doğrultuda alan yazında genellikle üç beceri en özel yürütücü işlev becerisi olarak tanımlanır, bunlardan en yaygın olanları önleyici kontrol, çalışma belleği ve bilişsel esnekliktir (Huizinga, Dolan ve Molen, 2006; Lehto, Juujärvi, Kooistra, ve Pulkkinen, 2003; St, Clair-Thompson ve Gathercole, 2006). Günlük yaşamdaki pek çok davranışın, sorunsuz çalışabilmesi için bu yürütücü işlev becerilerine ihtiyaç vardır (Barkley, 1997; Pennington ve Ozonoff, 1996). Çünkü yürütücü işlevler, düşüncelerimizi hedefe yönelik bir şekilde düzenleyebilmemize aracılık eder ve bu nedenle de okul ve iş durumlarının yanı sıra günlük yaşam becerileri için de gereklilik arz eder. Zira sürekli değişen bir ortamda, yürütücü işlev becerileri zihnimizi hızla değiştirmemize, karşılaştığımız çeşitli durumlara uyum sağlamamıza ve aynı zamanda uygunsuz davranışları engellememize yardım eder (Ardila ve Surloff, 2004). Bu yüzden de yürütücü işlevler, kişinin davranışlarını organize edebilme, yani kendini yönetebilme becerisinden oluşmaktadır (Tuncer, 2018; Tuncer ve Avc1, 2019).

Yürütücü işlevlerin geliştirilmesine yönelik yaklaşımlar çalışma belleği ve önleyici kontrolünün önemine dikkat çekmektedirler (Brocki ve Tillman, 2014; Carlson ve Moses, 2001; Oh ve Lewis, 2008; Zelazo, Müller, Frsye, ve Marcovitch, 2003). Çalışma belleği bilgiyi depolayan ve işleyen eş zamanlı 
bir işlemdir ve mantık yürütmede önemli bir etkiye sahiptir (Baddeley, 2006, 2012). Çalışma belleği teorisi ilk olarak Baddeley ve Hitch (1974) tarafından ortaya atılmıştır. Kısaca, çalışma belleği, bilgileri geçici olarak saklayabilme ve değiştirme yeteneğini ifade eder (Baddeley, 2012). Çalışma belleği bilgiyi akılda tutmak ve onunla zihinsel olarak çalışmak demektir. Zaman içinde ortaya çıkan her şeyi anlamlandırmak için son derece önemlidir, çünkü daha önce olanları akılda tutmak ve bunu şimdi olanla ilişkilendirmek çalışma belleğine bağlıdır. Bu nedenle, okunan ya da duyulan herhangi bir bilgiyi mantıklı kılmak için çalışma belleği gereklidir (Tuncer, 2018). Ayrıca, zihinsel olarak yeniden düzenlenen öğeler için (örneğin, yapılacaklar listesini yeniden organize etmek gibi), sebep ve sonucun anlaşılması ve genel bir ilke edinmek veya eski fikirler arasında yeni ilişkileri görmek için bilgi parçalarını zihinsel olarak ilişkilendirmek daha önce olanları akılda tutmak, daha sonra gelen bilgiyle ilişkilendirmek, perspektifleri değiştirmek veya değişen taleplerin ya da önceliklerin sıralamasını değiştirmek için kritik önem taşımaktadır. (Diamond, 2013).

Birtakım çalı̧malar, çalışma belleği kavramının çocukların kısa süreli bellekte öğrendiklerini depolama ve kontrol etme süreçlerini kapsadığından okul zamanı başladığını ifade etmektedir (Alloway ve Alloway, 2010; Anderson, 2002; Storbeck ve Maswood, 2016). Gerçekte çalışma belleğinde var olan zayıflıklar okula başlama süreciyle birlikte ortaya çıkmaktadır. Bu zayıflıklara sahip olan çocuklar akademik zorluklarla baş etmekte güçlük yaşamaktadırlar (Tuncer, 2018). Yapılan çalışmalar, merkezi yürütücü işlev görevlerinde başarısız olan çocukların, okuma (Swanson ve Holton, 2001), matematik (Swanson, 2001) ve okuduğunu anlama (Gathercole, Brown ve Pickering, 2003) alanlarında çeşitli problemler yaşadıklarını belirlemiştir. Bazı araştırmalar ise en azından altı yaşından önce, bilişsel yeteneklerin çoğunda olduğu gibi, bu alanlarda çalışma belleği yeteneklerini tam anlamıyla belirlemenin mümkün olmadığını ifade etmektedir. (Baddeley, Cocchini, Della Sala, Logie ve Spinnler, 1999). Ancak bazı kaynaklarda da yürütücü işlev becerilerinin en önemli üç bileşeninden biri olan çalışma belleğinin erken çocukluk yıllarında gözlemlenebilecek düzeye geldiği, bu yüzden de belirlenebileceği hatta ölçülebileceği yönündedir (Meltzer, 2018). Alan yazınındaki çalışmalar, çalışma belleği ile yürütücü işlev yapıları arasında anlamlı ilişkiler olduğunu ortaya koymaktadır (Lehto vd., 2003; McCabe, Roediger, McDaniel, Balota ve Hambrick, 2010). Bununla birlikte, çalışma 
belleği yapısının da yürütücü işlev becerilerinden biri olduğu kabul edilmektedir (McCabe vd., 2010). Bir diğer yürütücü işlev becerisi olan önleyici kontrol de ikinci tür yürütücü işlev becerileri arasında yer almakta ve uyarıcı durum ortadan kalktıktan sonra bile kendisi için önemli olan bilgileri hatırlayabilme, hareket etmeden önce ne olacağını ve bunun sonuçlarını tahmin edebilme ve çeşitli uyarıcıların dikkati dağıtmasına izin vermeden hedefine yoğunlaşabilmek gibi kişinin kendi davranışlarını düzenleme ve idare edebilme becerisini kapsamaktadır (Harris, 2016). Önleyici kontrol becerisi okula hazır olma açısından oldukça önem arz etmektedir (Tuncer, 2018). Önleyici kontrol becerisinin eksikliğinin yetişkinlik yıllarında dürtüsel karar vermeye yol açacağını vurgulayan araştırmacılar bulunmaktadır (Logan, Schachar ve Tannock, 1997). Bu yüzden de yürütücü işlev süreçlerinin içinde yer alan ve bilgiyi depolamak için gerekli olan çalışma belleği ile sıfır- iki yaş arasında ortaya çıkan ve ilk yürütücü işlev becerilerinden (Diamond ve Goldman-Rakic, 1989) sayılan önleyici kontrol becerilerinin erken yaşlarda kazanılmasının, çocukların günlük yaşam performanslarında önemli bir iyileşmeye neden olacağı söylenebilir (Tuncer, 2018). Barkley (1997) sönleyici kontrolün yürütücü işlevleri birleştiren merkezi bir bileşen olduğunu öne sürer. Garon vd., (2008) ise, önleyici kontrolün yürütücü işlevlerin başka bir yönü olan çalışma belleğine bağlı olduğunu ve ayrılabilir bir bileşen olmadığını savunmaktadır. Çünkü çalışma belleği ve önleyici kontrol çocukların okul yıllarındaki öğrenmelerini ve bununla birlikte yetişkinlikteki öğrenmelerini destekleme konusunda önemli bir role sahiptir (Alloway, 2006). Çünkü yürütücü işlev becerileri bireyin öğrenmesi ve etrafına uyum sağlaması için bir temel teşkil etmektedir (Tuncer, 2018). Bu yüzden de çocuklar yürütücü işlev becerilerinin bu önemli bileşenleri olan çalışma belleği ve önleyici kontrol konularında erken yaşlarda desteklenirlerse eğer, yürütücü işlevlerde meydana gelen gelişmeye bağlı olarak, bu çocukların kendilerini kontrol etmelerini sağlayan bütün zor görevlerin üstesinden gelmeye çalıştıkları ve bunu başardıkları gözlemlenebilir (Brown, Odom, McConnell ve Rathel, 2008).

Erken yıllardan itibaren çocuğu bulunduğu gelişim döneminin özelliklerine göre hazırlamak önemli bir amacı oluşturmalıdır. Bu amaca ulaşmak için ise gelişim ve öğrenmenin en hızlı olduğu okul öncesi dönemden başlamak gerekir. Çünkü erken çocukluk yılları öğrenmenin çok hızlı ve kalıcı 
olduğu, aynı şekilde büyük bir hızla zekânın geliştiği muhteşem yılları kapsamaktadır (Tuncer, 2018).

Yürütücü işlevlerin akademik başarıyı ve öğrenmeyi etkileyen en önemli etkenlerden biri olduğunu gösteren pek çok araştırma mevcuttur (Anderson, 2002, 2008; Cooper-Kahn ve Foster, 2013; Corcoran ve 'Flaherty, 2017; Goldstein, Naglieri, Princiotta ve Otero, 2014; Harris, 2016; Vitiello ve Greenfield, 2017; Zelazo, Craik ve Booth, 2004; Zelazo, Müller, Frye ve Marcovitch, 2003). Örneğin, Cartwright (2012)'ın araştırmasında yürütücü işlev becerilerinin erken okuma gelişiminde rol oynadığını bulmuştur. Bütün bu araştırmalarda, yürütücü işlevlerin temelinde yer alan çalışma belleği ve önleyici kontrol gibi iki önemli göreve işaret etmektedir (Carlson ve Moses, 2001; Oh, ve Lewis, 2008; Zelazo vd., 2003). Bu görevler okul öncesinden itibaren planlı bir şekilde desteklenerek geliştiğinde yürütücü işlevlerin bilinçli olarak kullanımı çoğalarak ilerleyeceğinden çocuklar yalnızca okul hayatlarında değil yaşamlarının tüm alanında bilişsel farkındalığı yüksek, davranışlarını kontrol edebilen ve kendi hayatları için sorumluluk alabilen bireyler haline dönüşeceklerdir (Tuncer, 2018). Çünkü okul öncesi dönemde planlanan bir düzenleme onların akademik başarıları içinde bir alt yapı oluşturarak ve hayata uyum sağlama becerilerini hızlandırarak daha ileri seviyelere taşıyacaktır. Zira güncel çalışmalar yürütücü işlev becerilerinin bebeklik ve erken çocukluk döneminde ortaya çıktığını; soyut düşünme ve karmaşık problem çözme gibi daha karmaşık becerilerin gelişimi için altyapı oluşturduğunu vurgulamaktadır (Best \& Miller, 2010; Dilworth-Bart, 2012). Başka bir çalışmada ise, 5-17 yaş arasındaki çocuklarda karmaşık yürütücü işlevler ve akademik başarı arasında ilişki olduğu ve yaşla birlikte bu ilişkinin değiştiği saptanmıştır (Best, Miller, \& Naglieri, 2011). Aynı envanterin kullanıldığı güncel bir çalışmada ise 48-66 ay arasındaki çocukların geometrik şekilleri tanıma testi daire alt boyutu ile ÇDYİE arasında anlamlı ilişki olduğu bulunmuştur (Öğütcen, 2020). Yine, Tuncer'in (2021) Türk ve mülteci çocukların yürütücü işlev becerilerini karşılaştırmak amacıyla yaptığı çalışmada Türk ve mülteci çocukların bilişsel esneklik puanları arasında anlamlı bir farklılık olduğunu bulmuştur. Okul öncesi dönem çocuklarının yürütücü işlev becerilerini değerlendiren envanterlerinin olduğu ancak çocukların ilk öğretmenleri olarak sayılan ebeveynlerin onları değerlendirdiği yeteri sayıda envanter olmadığı, bu yüzden de daha önce ilkokul çocukları için uyarlaması yapılan ÇDYİE'nin okul öncesi dönem çocuklarında 
kullabılabilmesi ve alan çalışmalarına bir ölçme aracı kazandırılmasının önemli bir ihtiyacı gidereceği düşünülmektedir. Bu envanterin çeşitli değişkenlerle olan ilişkisinin incelenmesi de ölçme aracının yapısının anlaşılmasına ciddi bir katkı sağlayacaktır.

Bu doğrultuda, bu çalışmanın amacı 48-72 aylık çocukların yürütücü işlevlerinin Çocukluk Dönemi Yürütücü İşlevler Envanteri'ne (ÇDYİE) dayalı olarak bazı değişkenler açısından incelemektir. Bu amaçla aşağıdaki sorulara cevap aranmıştır:

1. 48-72 aylık çocukların Çocukluk Dönemi Yürütücü İşlevler Envanteri'ine göre çalışma belleği ve önleyici kontrol alt boyutlarındaki ve toplamdaki becerileri cinsiyetine göre anlamlı bir farklılık göstermekte midir?

2. 48-72 aylık çocukların Çocukluk Dönemi Yürütücü İşlevler Envanteri'ine göre çalışma belleği ve önleyici kontrol alt boyutlarındaki ve toplamdaki becerileri yaşına göre anlamlı bir farklılık göstermekte midir?

3. 48-72 aylık çocukların Çocukluk Dönemi Yürütücü İşlevler Envanteri'ine göre çalışma belleği ve önleyici kontrol alt boyutlarındaki ve toplamdaki becerileri kardeş sayısına göre anlamlı bir farklılık göstermekte midir?

4. 48-72 aylık çocukların Çocukluk Dönemi Yürütücü İşlevler Envanteri' ine göre çalışma belleği ve önleyici kontrol alt boyutlarındaki ve toplamdaki becerileri doğum sırasına göre anlamlı bir farklılık göstermekte midir?

\section{Yöntem}

\section{Araştırma Deseni}

Araştırmada yer alan verilerin analizi dikkate alındığında, araştırma betimsel tekniklerin yanı sıra hem gruplar arası karşılaştırmaları hem de koralasonel analizleri gerektirmektedir. Bu nedenle araştırma çocukların yürütücü işlev becerilerinin belirlenebilmesi amacıyla genel tarama modeli türlerinden, ilişkisel tarama modeliyle dizayn edilmiştir. İlişkisel tarama modeli; iki ya da daha fazla sayıdaki değişkenin içinden birlikte değişim varlığı veya derecesini belirlemeyi amaç edinen, bir araştırma modelidir (Karasar, 2005; Kırcaali İftar, 1998). Bu çalışmada ilişkisi incelenecek değişkenler ise yürütü- 
cü işlev becerilerinden çalışma belleği ile önleyici kontrol becerisi ile cinsiyet, yaş, doğum sırası ve kardeş sayısı gibi değişkenlerdir.

\section{Çalışma grubu}

Bu araştırma, Tokat İl Merkezi'nde bulunan farklı okul öncesi eğitim kurumlarına devam eden çocukların ebeveynlerinden elde edilen verilere dayalı olarak gerçekleştirilmiştir. Bu kapsamda çalışma iki ayrı çalışma grubu üzerinde yürütülmüsstür. Bunlardan birincisi, Çocukluk Dönemi Yönetici İşlevler Envanteri'inin geçerlik ve güvenirlik çalışmalarının tespitine yönelik olarak ulaşılan 48-72 aylık dönemdeki çocuklar ile bunların ebeveynlerini temsil etmektedir. İkincisi de öncesinde tespit çalışmaları yapılmış Çocukluk Dönemi Yönetici İşlevler Envanteri'nin bazı değişkenler açısından yordanma gücünün incelenmesine yönelik olarak ulaşlan 48-72 aylık dönemdeki çocuklar ile bunların ebeveynlerini temsil etmektedir. Birinci çalışma grubu için Tokat İl Merkezi'nde bulunan okul öncesi eğitim kurumlarından tesadüfí örnekleme yöntemiyle belirlenen okullarda okul öncesi eğitim almakta olan 48-72 aylık dönemdeki 400 çocuk ile bu çocukların ebeveynleri belirlenmiştir. Bu kapsamda, geçerlik ve güvenilirlik süreçleri için dağıtılan 400 envanterden 349 tanesi geri dönmüştür. Geri dönen ölçeklerden dokuz tanesi eksik doldurma söz konusu olduğundan veri setinden çıarılmış ve 340 anket geçerlik güvenilirlik analizleri için değerlendirmeye alınmıştır. İkinci çalışma grubu ise Çocukluk Dönemi Yönetici İşlevler Envanteri'ne göre çocuklara ait bazı değişkenlerin etkisinin incelenmesine yönelik olacak şekilde Tokat ilinde bulunan Milli Eğitim Bakanlığı'na bağlı dokuz ilkokulun anasınıfında ve 4 dört bağımsız anaokulunda okul öncesi eğitime devam etmekte olan çocukları ile onların ebeveynlerinden oluşmaktadır. Bu kapsamdaki ebeveynler gönüllü olarak çalışmaya katılabileceğini bildiren ebeveynler arasından seçilmiştir. Buna göre, 48-72 aylık dönemdeki 349 çocuk ile bunların ebeveynleri ikinci çalışma grubunu oluşturmuştur. $\mathrm{Bu}$ gruba dahil olan çocukların demografik özelliklerine ait bulgular Tablo 1'de verilmiştir. 
Tablo 1. Çalışmanın örneklemini oluşturan çocukların demografik özelliklerine ilişkin bilgilerin dă̆ılımı

\begin{tabular}{|c|c|c|c|}
\hline & & $\mathrm{n}$ & $\%$ \\
\hline \multirow[t]{2}{*}{ Cinsiyet } & $\mathrm{K} \mathrm{iz}$ & 197 & 56,4 \\
\hline & Erkek & 152 & 43,6 \\
\hline \multirow[t]{3}{*}{ Yaş } & 4 & 61 & 17,5 \\
\hline & 5 & 154 & 44,1 \\
\hline & 6 & 134 & 38,4 \\
\hline \multirow[t]{3}{*}{ Kardeş sayısı } & Tek çocuk & 81 & 23,2 \\
\hline & İki kardeş & 98 & 28 \\
\hline & Üç ve üzeri kardeş & 170 & 48,7 \\
\hline \multirow[t]{3}{*}{ Doğum sırası } & İlk çocuk & 46 & 13,2 \\
\hline & Ortanca çocuk & 122 & 35,0 \\
\hline & Son çocuk & 181 & 51,8 \\
\hline
\end{tabular}

\section{Veri Toplama Araçlarn}

Çalışma amacı doğrultusunda, çalışma verilerini toplamak için, Kişisel Bilgi Formu ve Çocukluk Dönemi Yürütücü İşlevler Envanteri (Kayhan, 2010) (ÇDYİE) kullanılmıştır.

Kişisel Bilgi Formu :Çalışmada araştırmaya katılan çocukların özelliklerinin detaylı olarak açıklanabilmesi amacıyla, çocukların demografik bilgilerinin yer aldığı araştırmacı tarafından oluşturulan Kişisel Bilgi Formu kullanılmıştır. Bu formda, çocuğun doğum tarihi, cinsiyeti, doğum sırası ve kardeş sayısı hakkında bilgi sağlayacak sorulara yer verilmiştir.

Çocukluk Dönemi Yönetici İşlevler Envanteri (ÇDYiE): Bu çalışmada yürütücü işlev becerilerine ilişkin Thorell ve Nyberg (2008) tarafından, 4/7 yaş çocukları için geliştirilen ve Kayhan (2010) tarafından Türkçeye uyarlama ve geçerlik çalışması yapılan Çocukluk Dönemi Yürütücü İşlevler Envanteri (ÇDYİE) araştırmacı tarafından 48-72 aylık çocuklar için geçerlikgüvenilirlik analizleri yapılarak, çalışmada veri toplama aracı olarak kullanılmıştır (Kayhan, 2010). Çocukluk Dönemi Yürütücü İşlevler Envanteri orijinali Thorell ve Nyberg (2008) tarafından, 4/7 yaş çocukları için geliştirilmiş ve daha sonra (Catale, Lejeune, Merbah, ve Meulemans, 2013) tarafından da Fransızca konuşan üç-beş yaş Belçikalı çocuklar için adaptasyonu yapılmıştır. Envanter 26 maddeden oluşmuştur.

Türkiye'de Kayhan (2010) tarafından lisansüstü eğitim çalışması kapsaminda İstanbul ilinde devlet ve özel okullarda okuyan ilkokul birinci ve ikinci sınıfa devam eden altı yaş 11 aylık 68 ve 7 yaş üzeri 64 olmak üzere 
toplam 132 öğrenci üzerinde geçerlik ve güvenirlik çalışması yapılarak, Türkçe'ye uyarlanmıştır. Uyarlanan ölçekte çalışma belleğinde 13 madde, önleyici kontrolde 13 madde olmak üzere toplamda 26 madde bulunmaktadır. Kayhan (2010) tarafından yapılan uyarlama sonucu ölçeğin orijinal formunda bulunan 26 madde aynen korunmuştur. Türkiye'de uyarlama çalışması birinci ve ikinci sınıf öğrencilerinin ailelerinden ve öğretmenlerinden toplanan verilerin değerlendirilmesi sonucunda, ÇDYİE'nin yürütücü işlevlere yönelik davranışsal olarak veri sağlamada geçerli ve güvenilir bir ölçek olduğu belirtilmiştir. Hem öğretmen hem de ebeveynlerin yanıtladığ ölçek, tamamen katılıyorum ile tamamen katılmıyorum seçeneklerini barındıran 5'li Likert tipi bir ölçektir. Uyarlanan ölçekte Cronbach Alpha güvenirlik katsayısı; ebeveyn envanter için .91, öğretmen envanter için .97; çalışma belleği alt boyutu ebeveyn envanter için .86, öğretmen envanter için .95; engelleyici kontrol alt boyutu ebeveyn envanter için .82, öğretmen envanter için .90 'dır (Kayhan, 2010). Ancak bu envanter çalışmadaki yaş grubundan dolayı kullanılmadan önce 36-72 aylık çocuklar için ebeveyn örneklemine dayalı olarak Türkçe geçerlik-güvenirlik analizleri yapılmıştır. Çalışmaya başlamadan önce ölçeği geliştiren Thorell ve Nyberg'den (2008) e-posta aracılığıyla, ölçek kullanım izni alınmıştır. Aynı şekilde envanteri Türkçe'ye uyarlayan Kayhan (2010) ile de e-posta aracillğıyla görüşülerek, gerekli izinler için onayı alınmıştır. Envanterin dört-altı yaş uyarlamalarında da Kayhan'ın (2010) uyarladığı 26 maddelik ölçek formu kullanılmıştır.

Ölçeğin Geçerlik ve Güvenirlik İşlemleri: Çocukluk Dönemi Yürütücü İşlevler Envanteri'ni (ÇDYİE) Ebeveyn örneklemi için 340 katılımcı ile gerçekleştirilen DFA analizinde 2. ve 10. maddelerin standart değerleri .90'ın üzerinde çıktığından dolayı bu iki madde veri setinden çıkarılmış ve analiz tekrarlanmıştır. Bu maddeler çıkarıldıktan sonra gerçekleştirilen DFA analizinde hiçbir modifikasyona ihtiyaç duyulmadan kabul edilebilir uyum iyiliği indeksleri elde edilmiştir. DFA sonucunda elde edilen uyum iyiliği indeksleri Tablo 2' de ve yapısal eşitlik modeli ise Şekil 1'de sunulmuştur. 


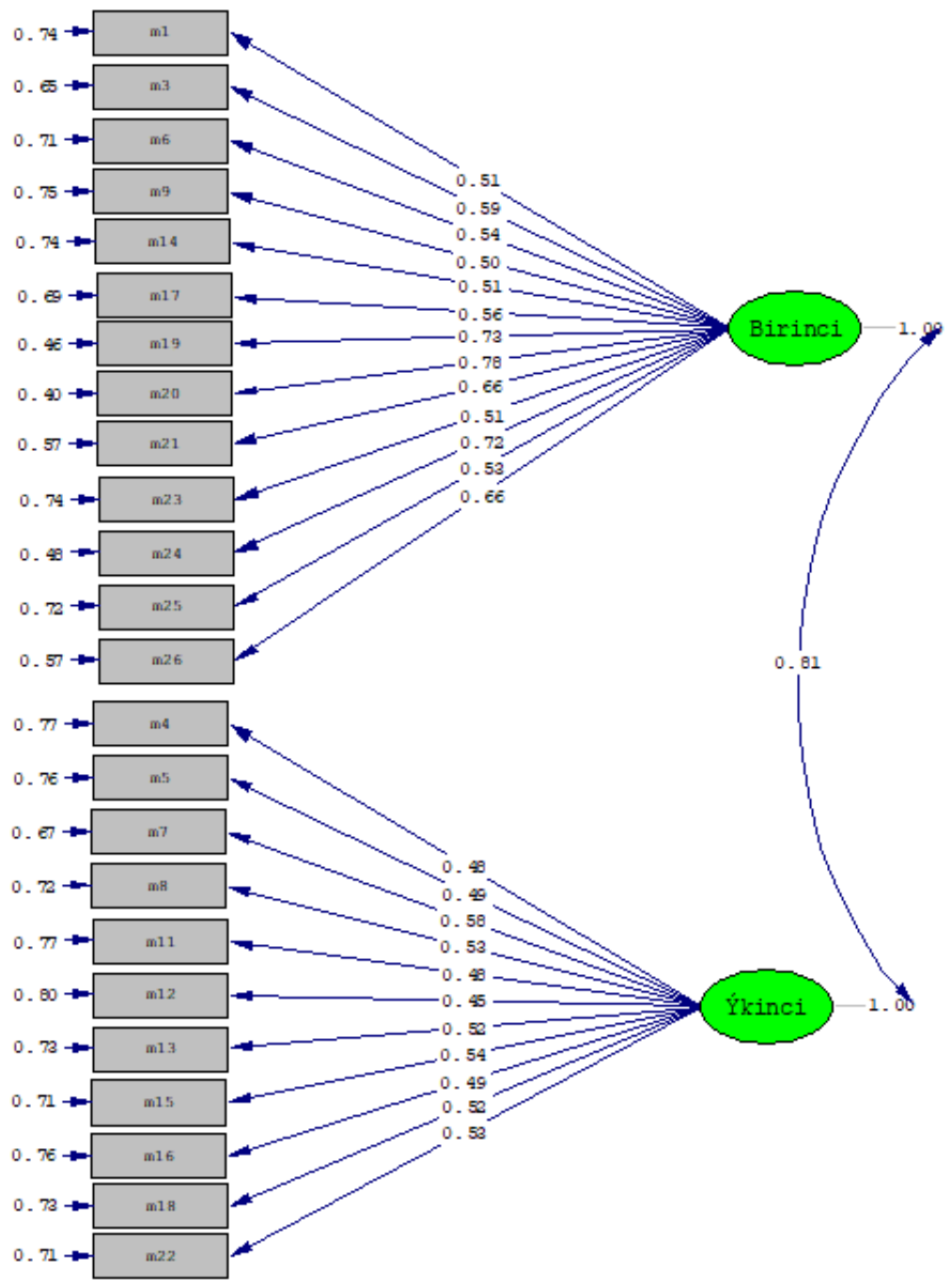

Chi-Square $=551.61, \mathrm{df}=251, \mathrm{P}-\mathrm{value}=0.00000, \mathrm{RMSEA}=0.059$

Şekil 1. Ebeveyn Örneklemi İçin Standart Değerler 
Tablo 2. Ebeveyn örneklemi için uyum iyiliği göstergeleri

\begin{tabular}{lll}
\hline Gösterge & Kabul Edilebilirlik Aralı̆̆ & Elde Edilen Değer \\
\hline $\mathrm{X} 2$ & & \\
\hline $\mathrm{P}$ & $\geq, 05$ (Hair ve diğerleri, 2006) &, 01 \\
\hline $\mathrm{x} 2 / \mathrm{sd}$ & $\leq, 3$ (Hair ve diğerleri, 2006) & 2,19 \\
\hline RMSEA & $\leq, 08$ (Hair ve diğerleri, 2006) &, 06 \\
\hline SRMR & $\leq, 08$ (Hair ve diğerleri, 2006) &, 08 \\
\hline $\mathrm{NFI}$ & $\geq, 90$ (Hair ve diğerleri, 2006) &, 93 \\
\hline $\mathrm{NNFI}$ & $\geq, 90$ (Hair ve diğerleri, 2006) &, 96 \\
\hline CFI & $\geq, 90$ (Hair ve diğerleri, 2006) &, 96 \\
\hline GFI & $\geq, 90$ (Hair ve diğerleri, 2006) &, 88 \\
\hline AGFI & $\geq, 90$ (Hair ve diğerleri, 2006) &, 86 \\
\hline
\end{tabular}

İlgili gözlenen değişkenin gizil değişken açısından önemini ortaya koyan önemli bir ölçüt her bir gözlenen değişken gizil değişkendeki değişimin ne kadarını açıklayabildiğini ortaya koyan $\mathrm{R}^{2}$ değeridir (Tabachnick ve Fidell, 2007). Modele ilişkin t değerleri incelendiğinde, tüm gözlenen değişkenlerin gizil değişken tarafından .01'lik anlamlılık düzeyinde yordanabildiği görülmektedir. Elde edilen $\mathrm{t}$ ve $\mathrm{R}^{2}$ değerleri ise Tablo $3^{\prime}$ de verilmiştir.

Tablo 3. Ebeveyn örneklemine ilişkin t ve $R^{2}$ değerleri

\begin{tabular}{lll}
\hline Madde & $\mathrm{t}$ değeri & $\mathrm{R}^{2}$ \\
\hline M1 & 9,57 &, 26 \\
M3 & 11,55 &, 35 \\
M4 & 8,65 &, 23 \\
M5 & 8,92 &, 24 \\
M6 & 10,22 &, 29 \\
M7 & 10,74 &, 33 \\
M8 & 9,70 &, 28 \\
M9 & 9,44 &, 25 \\
M11 &, 23 \\
M12 & 8,58 &, 20 \\
M13 & 7,96 &, 27 \\
M14 & 9,51 &, 26 \\
M15 &, 29 \\
M16 & 9,63 &, 24 \\
M17 &, 31 \\
M18 & 9,87 &, 27 \\
M19 & 8,82 &, 54 \\
M20 &, 60 \\
M21 & 10,68 &, 43 \\
M22 & 9,48 &, 29 \\
M23 & 15,21 &, 26 \\
M24 & 16,49 &, 52 \\
M25 & 16,49 &, 28 \\
M26 & 9,79 &, 43 \\
\hline
\end{tabular}


Analiz sonuçlarında görüldüğü üzere, $t$ ve $R^{2}$ değerleri kabul edilebilir sinurlardadır.

\section{Güvenirlik}

Ölçeğin güvenirliğini ortaya koymak amaciyla hem alt boyutlar hem de toplam puan bazında hesaplanan Cronbach Alpha $(\alpha)$ iç tutarlık katsayıları Tablo 4'de sunulmuştur.

\section{Tablo 4. Ölçek geneli ve alt boyutlan için Cronbach a değerleri}

\begin{tabular}{ll}
\hline Faktör Adı & Güvenirlik katsayısı \\
& $(\boldsymbol{\alpha})$ \\
Çalışma Belleği & .83 \\
Önleyici Kontrol & .80 \\
Ölçeğin Geneli & .88 \\
\hline
\end{tabular}

Ölçme aracında yer alan alt ölçeklerin ve genel toplamın güvenirliği için Tablo 4'de yer alan Cronbach Alpha iç tutarlıllk katsayıları incelendiğinde, Çalışma Belleği için $\alpha=.83$, Önleyici Kontrol $\alpha=.80$ ve genel toplam $\alpha=.88$ olduğu görülmektedir.

Bu tür ölçeklerde hesaplanan güvenirlik katsayısının .70 ve daha yüksek olması aracın güvenirliği için yeterli görülmektedir (Büyüköztürk, ÇakmakKılıç, Akgün, Karadeniz ve Demirel, 2014). Bu veriler doğrultusunda Çocukluk Dönemi Yürütücü İşlevler Envanteri'ni (ÇDYİE) dört-altı yaş çocuklarını değerlendirmede güvenilir bir ölçme aracı olduğuna karar verilmiştir.

\section{Verilerin Analizi}

Verilerin analizinde öncelikli olarak toplanan veriler analize dahil edilmeden önce cevapsız bırakılma veya birden fazla seçenek işaretleme durumlarına göre incelenmiştir. Uygun doldurulmayan formlar veri setine dahil edilmemiştir. Böylece geçerlik-güvenilirlik analizleri için 340 form ve çocuk değişkeni için 349 ölçek analiz edilmiştir. Öncelikle Çocukluk Dönemi Yürütücü İşlevler Envanteri'nin (ÇDYİE) geçerlik ve güvenilirlik analizleri yapılmıştır. 340 katılımcı ile gerçekleştirilen geçerlik güvenirlik analizlerinin ardından 2 ve 10. maddeler formdan çıkarılmış ve forma son şekli verilerek kullanılmıştır. Veri toplamada kullanılmış olan Kişisel Bilgi Formu ve geçerlik güvenirlik analizinden sonra 24 madde olarak oluşturulan Çocukluk Dönemi Yürütücü İşlevler Envanteri'nden elde edilen verilerin Sosyal Bilim- 
ler için İstatistik Paket Programı (SPSS) yardımı ile analiz edilmiş ve buna dayalı olarak yorumlanması yapılmıştır. Yapılan istatiksel çalışmalarda, H1 hipotezi için değişkenler arasında anlamlı bir farklılık vardır; H0 hipotezinin kabulü için değişkenler arasında anlamlı bir farklılık yoktur şeklinde hipotezler kurulmuş olup anlamlılık düzeyi olarak 0.05 veya 0.01 kabul edilmiştir. Örneğin; H1: "okul öncesi çocuklarının ebeveyn görüşlerine göre yürütücü işlev puanları cinsiyetlerine göre anlamlı bir farklılık göstermektedir" ve Ho: "öncesi çocuklarının ebeveyn görüşlerine göre yürütücü işlev puanları cinsiyetlerine göre anlamlı bir farklılık göstermemektedir" şeklinde hipotezler test edilmiştir. Kişisel bilgi formundan elde edilen demografik değişkenlerin frekans ve yüzdelik dağılımları gibi betimsel istatistikler hesaplanmıştır. Veri analizinde uygun analiz yöntemini belirlemek üzere öncelikle elde edilen verilerin normal dağılım gösterip göstermediğine bakılmıştır. Çalışmada elde edilen verilerin normalliğini test etmek için Kolmogorov-Smirnow testi kullanılmıştır. Kolmogorov-Smirnow testinin sonucuna göre formdan elde edilen puanların normal dağılım gösterdiğ $(n=340$, $\mathrm{p}>$.05) bulunmuştur. Bu nedenle verilerin analizinde iki gruptan oluşan değişkenler için parametrik testlerden bağımsız örneklemler için t-testi ve ikiden fazla gruptan oluşan değişkenler için Tek Faktörlü ANOVA kullanılmıştır. ANOVA sonucunda anlamlı farklılığın olduğu durumlarda farkl1lığın kaynağını belirlemek için de Tukey testi yapılarak, farkın hangi gruplar arasında olduğu saptanmıştır.

\section{Etik Bildirim}

Bu çalışma, Tokat Gaziosmanpaşa üniversitesi sosyal ve beşeri bilimler etik kurulu komisyonundan alınan izin (04.08.2020 tarih, 11 nolu toplantı, 10 nolu karar) çerçevesinde yapılmıştır.

\section{Bulgular}

Bu bölümde, her bir alt probleme yanıt bulmak üzere çalışma kapsamında elde edilen bulgulara yer verilmiştir.

Okul öncesi çocuklarının cinsiyetlerine göre yürütücü işlev becerilerinin farklılığına ilişkin bulgular Tablo 5'de sunulmuştur. 
Tablo 5. Okul öncesi çocuklarnın ebeveyn görüşlerine göre yürütücü işlev becerileri puanlarını cinsiyete göre t-testi sonuçları

\begin{tabular}{llllllll}
\hline Yürütücü işlevler & Cinsiyet & $\mathrm{N}$ & $\overline{\mathrm{x}}$ & $\mathrm{S} . \mathrm{s}$ & $\mathrm{sd}$ & $\mathrm{t}$ & $\mathrm{p}$ \\
\hline Çalışma Belleği & Kadın & 197 & 28,4010 & 7,91386 & 347 &, 971 &, 332 \\
\cline { 2 - 8 } & Erkek & 152 & 27,5395 & 8,59607 & & & \\
\hline \multirow{2}{*}{ Önleyici Kontrol } & Kadın & 197 & 29,7665 & 6,35805 & 347 & $-1,054$ &, 293 \\
\cline { 2 - 8 } & Erkek & 152 & 30,5724 & 7,92063 & & & \\
\hline \multirow{2}{*}{ TOPLAM } & Kadın & 197 & 58,1675 & 12,88439 & 347 &,- 037 &, 971 \\
\cline { 2 - 8 } & Erkek & 152 & 58,1118 & 15,27694 & & & \\
\hline
\end{tabular}

Tablo 5’de görüldüğü gibi, okul öncesi çocuklarının yürütücü işlev becerilerinden çalışma belleği ve önleyici kontrol puanlarının cinsiyetlerine göre anlamlı olarak farklılaşıp farklılaşmadığını belirlemek için yapılan bağımsız örneklemler için $\mathrm{t}$ testi sonucunda, kızlar ve erkeklerin çalışma belleği (kız için $\bar{x}=28,40$ ve erkek için $\bar{x}=27,53$ ), önleyici kontrol belleği (k1z için $\bar{x}=29,76$ ve erkek için $\bar{x}=30,57)$ ve toplam ( $k$ ız için $\bar{x}=58,16$ ve erkek için $\bar{x}=58,11$ ) puanları arasındaki anlamlı bir farklılığın olmadığı sonucuna ulaşılmıştır $(\mathrm{p}<.05)$.

Okul öncesi çocuklarının yaşlarına göre yürütücü işlev becerilerinin farklılığına ilişkin bulgular Tablo 6’da sunulmuştur.

Tablo 6. Okul öncesi çocuklarnın ebeveyn görüşlerine göre yürütücü işlev becerileri puanlarının çocukların yaşlarına göre tek faktörlü anova sonuçları

\begin{tabular}{|c|c|c|c|c|c|c|}
\hline & Varyansın Kaynağı & Kareler Toplamı & sd & Kareler Toplamı & $\mathbf{F}$ & $p$ \\
\hline \multirow{3}{*}{$\begin{array}{l}\text { Çalışma } \\
\text { Belleği }\end{array}$} & Gruplararası & 82.970 & 3 & 27,657 & ,408 & ,748 \\
\hline & Gruplariçi & 23413,798 & 345 & 67,866 & & \\
\hline & Toplam & 23496,768 & 348 & & & \\
\hline \multirow{3}{*}{$\begin{array}{l}\text { Önleyici } \\
\text { Kontrol }\end{array}$} & Gruplararası & 110,611 & 3 & 36,870 & ,734 &, 533 \\
\hline & Gruplariçi & 17341,572 & 345 & 50,265 & & \\
\hline & Toplam & 17452,183 & 348 & & & \\
\hline \multirow{3}{*}{ Toplam } & Gruplararası & 359,732 & 3 & 119,911 & 614 & ,607 \\
\hline & Gruplariçi & 67419,105 & 345 & 195,418 & & \\
\hline & Toplam & 67778,837 & 348 & & & \\
\hline
\end{tabular}

Okul öncesi çocuklarının yürütücü işlev becerilerinden çalışma belleği ve önleyici kontrol puanlarının çocukların yaşlarına göre anlamlı bir şekilde farklılaşıp farklılaşmadığını belirlemek için yapılan Tablo 6'daki Tek Faktörlü ANOVA analizi sonuçlarına göre; çocukların yaşlarına göre yürütücü işlev becerilerinin Çalışma Belleği ( $\left.\mathrm{F}_{[3-345]}=.408, \mathrm{p}>.05\right)$, Önleyici Kontrol ( $\mathrm{F}_{[3-}$

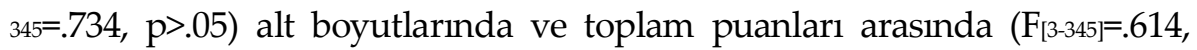
p>.05) anlamlı bir farklılık göstermediği sonucuna ulaşılmıştır. 
Okul öncesi çocuklarının kardeş sayısına göre yürütücü işlev becerilerinin farklılığına ilişkin bulgular Tablo 9'da sunulmuştur.

Tablo 9. Okul öncesi çocuklarnnn ebeveyn görüşlerine göre yürütücï işlev becerileri puanlarınin çocukların kardeş sayısina göre tek faktörlï anova sonuçlar

\begin{tabular}{|c|c|c|c|c|c|c|}
\hline & Varyansın Kaynağı & Kareler Toplamı & sd & Kareler Toplamı & $\mathbf{F}$ & $p$ \\
\hline \multirow{3}{*}{$\begin{array}{l}\text { Çalışma } \\
\text { Belleği }\end{array}$} & Gruplararası & 263,678 & 3 & 87,893 & 1,305 & 273 \\
\hline & Gruplariçi & 23233,090 & 345 & 67,342 & & \\
\hline & Toplam & 23496,768 & 348 & & & \\
\hline \multirow{3}{*}{$\begin{array}{l}\text { Önleyici } \\
\text { Kontrol }\end{array}$} & Gruplararası & 58,259 & 3 & 19,420 & ,385 & ,764 \\
\hline & Gruplariçi & 17393,925 & 345 & 50,417 & & \\
\hline & Toplam & 17452,183 & 348 & & & \\
\hline \multirow{3}{*}{ Toplam } & Gruplararası & 338,597 & 3 & 112,866 &, 577 & ,630 \\
\hline & Gruplariçi & 67440,239 & 345 & 195,479 & & \\
\hline & Toplam & 67778,837 & 348 & & & \\
\hline
\end{tabular}

Tablo 9'da görüldüğü gibi, okul öncesi çocuklarının kardeş sayısına göre yürütücü işlev becerilerinden çalışma belleği ve önleyici kontrol puanlarının anlamlı olarak farklılaşıp farklılaşmadığını belirlemek için yapılan Tek Faktörlü ANOVA analizi sonuçlarına göre; çocukların yaşlarına göre yürütücü

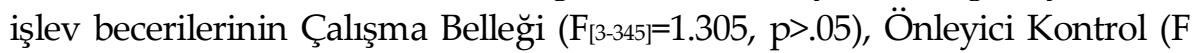

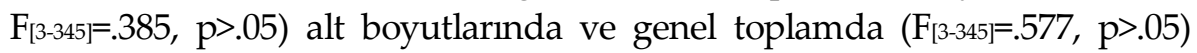
anlamlı bir farklılık göstermediği sonucuna ulaşılmıştır.

Okul öncesi çocuklarının doğum sorasına göre yürütücü işlev becerilerinin farklılı̆̆ına ilişkin bulgular Tablo 10'de sunulmuştur.

Tablo 10. Okul öncesi çocuklarnın ebeveyn görüşlerine göre yürütücü işlev becerileri puanlarının doğum sırasına göre tek faktörlü anova sonuçları

\begin{tabular}{|c|c|c|c|c|c|c|c|}
\hline & $\begin{array}{l}\text { Varyansın } \\
\text { Kaynağı }\end{array}$ & $\begin{array}{l}\text { Kareler } \\
\text { Toplamı }\end{array}$ & sd & $\begin{array}{l}\text { Kareler } \\
\text { Toplamı }\end{array}$ & F & $p$ & $\begin{array}{l}\text { Anlamlı } \\
\text { Fark }\end{array}$ \\
\hline \multirow{3}{*}{$\begin{array}{l}\text { Çalışma } \\
\text { Belleği }\end{array}$} & Gruplararası & 1217,079 & 2 & 608,540 & 9,485 & 00 & $1-2$ \\
\hline & Gruplariçi & 22134,654 & 345 & 64,158 & & & $1-3$ \\
\hline & Toplam & 23351,733 & 347 & & & & \\
\hline \multirow{3}{*}{$\begin{array}{l}\text { Önleyici } \\
\text { Kontrol }\end{array}$} & Gruplararas1 & 457,247 & 2 & 228,624 & 4,655 & 01 & $2-3$ \\
\hline & Gruplariçi & 16944,132 & 345 & 49,113 & & & \\
\hline & Toplam & 17401,379 & 347 & & & & \\
\hline \multirow{3}{*}{ Toplam } & Gruplararası & 2539,127 & 2 & 1269,564 & 6,752 & ,001 & $1-3$ \\
\hline & Gruplariçi & 64872,192 & 345 & 188,035 & & & \\
\hline & Toplam & 67411,319 & 347 & & & & \\
\hline
\end{tabular}

Tablo 10 'da yer alan çocukların doğum sırasına göre çalısma belleği ve önleyici kontrol puanları üzerinde ve genel toplamda anlamlı olarak farkl1laşıp farklılaşmadığını belirlemek için yapılan Tek Faktörlü ANOVA analizi 
sonuçlarına göre; çocukların doğum sırasına göre Çalışma Belleği ( $F_{[2-}$ $345=9.485, \mathrm{p}>.05)$, Önleyici Kontrol $\left(\mathrm{F}_{[2-345]}=4.655, \mathrm{p}>05\right)$ boyutlarında ve top-

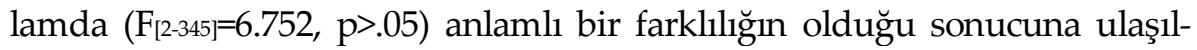
mıştır. Bu farklılığın hangi gruplar arasında olduğunu belirlemek üzere yapılan Tukey testi sonucunda, farklılığın Çalışma Belleği boyutunda ilk çocuk ile ortanca ve son çocuk arasında, ilk çocuk lehine anlamlı olduğu saptanmıştır ( $\mathrm{p}<.01)$. Önleyici Kontrol boyutunda ise ortanca çocuk ile son çocuk arasında ortanca çocuk lehine anlamlı düzeyde bir farklılaşmanın olduğu görülmüştür $(\mathrm{p}<01)$. Yürütücü işlev becerilerinin toplamında ise ilk çocuk ile son çocuk arasında ilk çocuk lehine anlamlı düzeyde bir farklılığın olduğu belirlenmiştir $(\mathrm{p}<.01)$.

\section{Tartışma ve Sonuç}

Yürütücü işlevler çocuklar için eşsiz bir bilişsel yapının varlığını işaret etmektedir. Çünkü içinde barındırdığı bellek fonksiyonları sayesinde öğrenme gerçekleşir (Dehn, 2008; 2010). Yürütücü işlev becerilerinin en önemli bileşenlerinden olan çalışma belleği ve önleyici kontrol öğrenme üzerinde en etkili yapıdır. Çalışmanın sonuçları, çocukluk dönemi yürütüicü işlev becerileri ebeveyn formuna göre 48-72 aylık çocukların çalışma belleği ve önleyici kontrol becerilerinin cinsiyete, yaşa ve kardeş sayllarına göre değişmediğini göstermektedir. İlgili alanyazında, çalışma belleği ve önleyici kontrol boyutunda cinsiyete göre değişip değişmediğini sorgulayan ve farklı sonuçları olan araştırmalar bulunmaktadır. Örneğin; birkısım çalışma Blasiman ve Was;2018; Camerota,, Willoughby, Kuhn, ve Blair, (2018) cinsiyete göre anlamlı bir fark olduğunu tespit etmiştir. Yani bu çalışmaların sonuçları erkek çocuklarının kız çocuklarına göre hem çalışma belleği hem de önleyici kontrolde daha yüksek puan aldıkları yönündedir. Hamamc'nın (2020) aynı ölçekle yaptığı çalışmada ise önleyici kontrol becerisinin kız çocuklarının lehinde farklılaştı̆̆ı görülmüştür. Formun öğretmen değerlendirmesinde ise önleyici kontrol becerisinin kız çocuklar lehine farklılaştığı da bulmuştur. Sağlam (2020) ise okul öncesi çocuklarıyla yaptı̆̆ı araştırmasında çalışma belleği puanlarında erkeklerin kızlardan daha yüksek puan aldığını bulmuştur. Bununlar birlikte, Decker (2011) dört-altı yaş çocuklarının çalışma belleği ve erken akademik becerilerle olan ilişkiye baktığ çalışmasında sözel beceriler ve işitsel kısa süreli bellek arasında anlamlı bir ilişki söz konusu iken, cinsiyetler arası bir fark bulunamamıştır. Buna kar- 
şın, çeşitli yaştan bireylerle gerçekleştirilen bir başka araştırmada ise sadece 13-15 yaş grubundaki erkek çocukların çalışma belleğini ölçen üç testten ikisinde kızlardan daha yüksek performans gösterdiği bulunmuştur (Gathercole vd., 2004). Ancak cinsiyetin çalışma belleğini etkileyen bir faktör olup olmadığının anlaşılması için daha çok araştırmaya ihtiyaç duyulduğu ifade edilmiştir (Doğan,2011). Bahsi geçen bu noktadaki çalışmalar da bu araştırmanın çıktılarını doğrular şekilde, cinsiyet değişkenine göre anlamlı bir fark olmadığını bulmuştur. Ancak cinsiyet farkının anlamlı olmadığını bulan bazı çalışmalarda, ebeveynlerin önyargılı olmasının olasılığı ile açıklamaya çalışılmıştır. Ebeveynin stresinin ve depresyonunun çocukların davranışlarına ilişkin algılarını etkileyebileceği de ifade edilmiştir (Joyner, Silver ve Stavinoha, 2009; Silver, 2014). Ancak bu çalışmada cinsiyete göre anlamlı düzeyde bir fark çıkmamasının nedeni, ebeveynlerin değerlendirmeyi daha objektif yapmış olabileceği yönünde bir görüş ile açıklanabilir.

Çalışmanın bir diğer sonucu ise çocukluk dönemi yürütücü işlev becerilerinin yaşa göre anlamlı bir farklılık göstermediği yönündedir. Yürütücü işlevler genel olarak karmaşık görevlerin sürdürülmesi, çalışma belleği, strateji oluşturabilme ve önleyici kontrol gibi bilişsel fonksiyonların sürdürülmesinde rol önemli bir rol oynamaktadır ve yaşla beraber artan bir performansa sahiptir. (Ertuğrul, 2011; Goldstein vd., 2014; Harris, 2016; Verdine, Irwin, Golinkoff ve Hirsh-Pasek, 2014). Zira çalışma belleği kapasitesinin çocukluk döneminde yaşla beraber arttı̆̆1 ve bu kapasitenin en erken dört yaşında ölçülebildiği sıklıkla dile getirilmesine rağmen (Alloway vd., 2008), yaş faktörünün çalışma belleği üzerinde etkili olduğunu belirtmek güçtür (Gathercole vd., 2004a). Ancak bazı araştırmacılar çalışma belleği becerilerinin dört yaşına kadar sabit kaldığını ifade etmektedir (Gathercole vd., 2004b). Bunun yanı sıra, çalışma belleği tıpkı diğer süreçlerin gelişimi gibi yaş, cinsiyet, sosyo ekonomik durum ve erken müdahale programlarından da etkilenmektedir (Doğan, 2011). Literatürdeki gelişimsel çalışmalar, çalışma belleği kavramının dört yaşında ortaya çıktığı, altı yaşındayken bir ivme kazandığı ve ergenlik çağında gelişimine devam ettiğini ileri sürmektedir (Ertuğrul, 2011; Gathercole, Pickering, Ambridge ve Wearing, 2004). Gathercole vd.'nin (2004) yaptığ çalışmada, 13 ve 15 yaş grubunda erkek ergen bireylerin çalışma belleğinden görsel mekansal yapıyı ölçen üç testten ikisinde kız ergen bireylere göre yüksek başarı gösterdiği belirtilmektedir (Gathercole vd., 2004a). Ancak yapılan çalışmalarda cinsiyet farkının ileri 
yaşlarda ortaya çıtı̆̆g görülmektedir. Zira Gathercole vd. (2004b) 4-11 yaş arası çocuklarda sözel ve görsel kısa süreli bellek ve çalışma belleğinin yapısını araştırdıkları çalışmalarında cinsiyet ile ilgili görevlerin hiçbirinde bir fark bulunmadığı sonucuna ulaşmışlardır. Hamamcı (2020) 36-71 aylık çocuklarla yaptığ çalışmada önleyici kontrol becerilerinde yaşa göre anlamlı bir fark olmadığını bulmuştur. Bu araştırmanın sonucu da bu bulgularla tutarlı görünmektedir. Öte yandan, baskın tepkileri durdurma becerisi olup otomatik davranışlar yerine uyumlu davranışlar sergilemek olarak tanımlanan (McClelland vd., 2007a) ve alanyazında, ilk yürütücü işlev becerilerinden biri olarak açıklanan önleyici kontrol, sıfır-iki yaş arasında ortaya çımaktadır (Diamond ve Goldman-Rakic, 1989). Barkley, (1997) önleyici kontrol becerilerinin yürütücü işlevleri birleştiren merkezi bir bileşen olduğunu öne sürmektedir Garon, Bryson. ve Smith, (2008) ise önleyici kontrol becerilerinin yürütücü işlevlerin başka bir yönüne, yani çalışma belleğine bağlı olduğunu ve ayrılabilir bir bileşen olmadığını savunmaktadır.

Oh ve Lewis (2008) üç-beş yaş Koreli, İngiliz ve Türk çocuklarının, önleyici kontrol durumlarıyla, diğer yürütücü işlevler ve zihinsel durumları arasındaki ilişkiyi konu aldıkları araştırma sonucunda, çocukları kültürlerarası farklar yönünden incelenmişlerdir. Araştırma sonucunda, Koreli çocukların bazı yürütücü işlev fonksiyonlarında diğer kültürdeki çocuklara göre yetersiz performans göstermelerine rağmen, önleyici kontrol becerisinde üst düzey bir performans sergilediği görülmüştür. Araştırma kültürün yürütücü işlevlerin geneli üzerinde anlamlı bir etkiye sahip olmadığını ifade ederken, Koreli üç yaş çocuklarının, önleyici kontrol davranışlarında İngiliz beş yaş çocuklarından bile yüksek performans sergilemiş olmalarını Kore kültüründe yer alan cezalandırıcı ebeveyn tutumlarıyla açıklamıştır. Diamond (2002), önleyici kontrolün bebekliğin ilk yılında, yani birinci yaşın sonlarına doğru ortaya çıktığını fakat çocuğun yürümeye başladıktan sonra ve okul öncesi yıllarında önemli değişimlere uğradığını söylemektedir. Zira yaşamın ilk yıllarında ortaya çıkn önleyici kontrol yeteneği ile çocuklar erken yıllara uygunsuz davranışları engellemede giderek daha çok ustalık kazanmaktadırlar. (Garon vd., 2008). Mevcut çalışmada yaş değişkeninde anlamlı farklılıkların bulunmamasının sebebinin de yaş gruplarının birbirine yakın olmasından kaynaklanabileceği düşünülmektedir. Çünkü çalışma $\% 17,54, \% 44,1$ beş yaş ve $\% 38$ ise altı yaş grubundan oluşmaktadır. Beş ve altı yaş çoğunluğu oluşturduğundan, dört yaş grubun \%17,5 gibi küçük bir 
dilimi kapsadığı için yaşa göre çalışma belleği ve önleyici kontrol becerilerinde anlamlı bir farklılık çıkmaması normal olarak değerlendirilebilir.

Araştırmanın bir başka sonucu ise kardeş sayısının çalışma belleği ve önleyici kontrol becerilerinde anlamlı bir farklılığa sebep olmadığıdır. Alınyazında yürütücü işlevler, bireyin davranış yeterliliklerini de içine alan bir grup yetenekten meydana geldiği ifade edilmektedir. Bunların içinde önleyici kontrol, çalışma belleği ve bilişsel esneklik olmak üzere üç temel yürütücü işlev bulunduğuna dair genel bir anlayış vardır. Bunlar, akıl yürütme, problem çözme ve planlama gibi daha üst düzey yürütücü işlev becerilerinin temelini oluşturur (Christoff, Ream, Geddes ve Gabrieli, 2003). Kardeş sayısının anlamlı bir fark yaratıp yaratmadığı konusunda litaretürde farklı çalışmalar mevcuttur. Örneğin; Sağlam (2020) çalışmasında kardeşi olmayan çocukların çalışma belleği becerilerinin kardeşi olanlara göre daha yüksek olduğunu bulmuştur. Ancak, yine de kardeş sayısının fark yaratmad1ğını söyleyen araştırmalar daha fazladır. Bir örnek olarak bakıldığında, Groen' in (2015) çocuklarda yürütücü işlevlerin gelişiminde aile faktörlerinin etkisini araştırdığ çalışmasında, 8 ile 12 yaş arasında bulunan toplam 437 çocukla yaptığı çalışmasında kardeşi olan ve olmayan çocuklar arasında yürütücü işlev puanları bakımından anlamlı bir farklılığın bulunmadığı ifade edilmiştir. Aynı şekilde önleyici kontrol becerilerinin öğretmen formuyla değerlendirildiği bir çalışmada ise önleyici kontrol becerisinin kardeşi olma durumuna göre farklılaşmadığı görülmüş̧ür (Hamamc1, 2020).

Araştırmacı tarafından yürütülen bu çalışmanın bir diğer sonucu ise, okul öncesi çocuklarının doğum sırası göre yürütücü işlev becerilerinden çalışma belleği ve önleyici kontrol alt boyutundaki puanlarının anlamlı olarak farklılaştığıdır. Çalışma Belleği boyutunda ilk çocuk ile ortanca ve son çocuk arasında, farkın ilk çocuk lehine anlamlı olduğu saptanmıştır. Önleyici kontrol boyutunda ise ortanca çocuk ile son çocuk arasında ortanca çocuk lehine anlamlı düzeyde bir farklılaşmanın olduğu sonucuna ulaşılmıştır. $\mathrm{Bu}$ bulgular, Holmgren, Molander ve Nilsson'un (2008)yürüttüğü epizodemik bellek (ansıal bellek) ve doğum düzeni etkilerini incelediği boylamsal türdeki bir araştırmanın bulgularıly paralellik göstermektedir. Araştırmada ilk doğum sırasına sahip olanların bellek performanslarının daha iyi olduğunu bulmuşlardır. İlk çocuk olanların performanslarının daha yüksek çıkmasının nedeni ise ebeveynlerin dikkat ve ilgilerini ilk çocuğa daha çok yoğunlaştırmalarından ve bu dikkat, ilgi ve kaliteli zaman geçirme fursatının 
bölünmemesinden kaynaklı olduğu düşünülebilir. Başka bir deyişle, aileler ilk çocuklarıyla daha çok ve daha nitelikli olarak ilgilendiklerinden ilk çocuğun bellek performansı diğer çocuklara göre daha iyi olabilir.

Yapılan analiz ve değerlendirmelerin sonuçları özetle ele alındığında; çalışmaya katılan 48-72 aylık çocukların çocukluk dönemi yürütücü işlev becerilerinin ebeveyn değerlendirmesine göre çalışma belleği ve önleyici kontrol becerilerinin cinsiyete, yaşa ve kardeş sayılarına göre değişmediği ortaya konmuştur. Bununla birlikte, çocukların doğum sırasına göre yürütücü işlev becerilerinin çalışma belleği, önleyici kontrol alt boyutlarında ve toplamda anlamlı bir farklılı̆̆ın olduğu sonucuna ulaşılmıştır. Bu farklılığın çalışma belleği boyutunda ilk çocuk ile ortanca ve son çocuk arasında, ilk çocuk lehine anlamlı olduğu saptanmıştır. Önleyici kontrol boyutunda ise ortanca çocuk ile son çocuk arasında ortanca çocuk lehine anlamlı düzeyde bir farklılaşmanın olduğu görülmüştür Yürütücü işlev becerilerinin toplamında ise ilk çocuk ile son çocuk arasında ilk çocuk lehine anlamlı düzeyde bir farklılığın olduğu belirlenmiştir.

Çalışmanın bulguları ışığında çocukların yürütücü işlevlerin en önemli iki bileşeni olan çalışma belleği ve önleyici kontrol becerilerini ölçecek farklı çalışmaların ortaya koyulması ve bu faktörlere bağlı olarak çocukların çalışma belleği ve önleyici kontrol becerilerini artıran çalışmaların yapılması önerilmektedir. Çocuklarla çalışanlara özellikle de öğretmenlere, yürütücü işlev becerileri hakkında ve bu becerileri destekleyici stratejilerin sınıflarında uygulanması için okul öncesi eğitimi programıla bütünleştirilmesine yönelik hizmet içi eğitimlerin verilmesi gerekmektedir. Erken çocukluk yıllarında çocukların çalışma belleği ve önleyici kontrol performanslarını artırmayı amaçlayan okul öncesi eğitim programları hazırlanarak uygulanması önerilmektedir. Ayrıca okul öncesi öğretmenlerinin çocukların çalışma belleği ve önleyici kontrol becerilerini geliştirmeye ve desteklemeye yönelik sinıf stratejilerini kullanabilmeleri için çeşitli eğitimler aracılığıyla desteklenmesi önerilmektedir. Çalışma belleği ve önleyici kontrol becerilerinin erken yıllarda desteklenmesi çocukların ilkokula okula hazır bulunuşluk düzeylerini de güçlendirerek daha iyi bir başlangıç yapmalarına yardımcı olacaktır. İleride yürütülecek çalışmalarda ise okul öncesi çocuklarının çalışma belleği ve önleyici kontrol becerilerini geliştirici eğitim programları hazırlanarak, programın etkililiğini deneysel çalışmalarla test eden araştırmaların yürütülmesi önerilmektedir. 


\title{
EXTENDED ABSTRACT \\ The Adaptation of the Parents' Form of the Childhood Executive Functioning Inventory for 48-72 Month Children and the Analysis of Its Predictive Power in Terms of Some Variables
}

\author{
Nuran Tuncer \\ Tokat Gaziosmanpaşa University
}

Executive functions is a term covering a range of cognitive processes such as problem solving, self-control skill and goal-directed behaviours (Camerota, Willoughby, Kuhn, and Blair, 2018). Also, as a blanket term, it includes metacognitive skills such as working memory, inhibitory control, mental flexibility and planning, which consist of some subskills such as adaptation to an environment, stimuli and to various stituations, goal setting and changing, doing plans, predicting results, responding by considering all these processes and controlling feelings as well (Baron, 2004, p.135; Garon, Bryson, and Smith, 2008; Thorell and Catale, 2014; Welsh, Nix, Blair, Bierman, and Nelson, 2010). Although the executive function skills develop during the first two decades of life, early childhood has been identified as the fastest developmental period (Garon et al., 2008). Hence, a good deal of effort has been put into assessing the executive function skills of preschool children. From the early years on, to prepare children according to the characteristics of the developmental period they are in must be an essential aim. In order to achieve this aim, it is necessary to start preparations in the preschool period, in which development is at its fastest because early childhood covers the golden years when permanent learning occurs fast and intelligence develops likewise (Tuncer, 2018).

Within this context, the aim of the study is to examine the 48-72 monthold children in terms of some certain variables on the basis of the Childhood Executive Functioning Inventory (CHEXI). For this purpose, the following questions have been searched. 
1. According to the Childhood Executive Functioning Inventory, do the dimensions of working memory and inhibitory control of the 48-72 month-old children and in total significantly vary by gender?

2. According to the Childhood Executive Functioning Inventory, do the dimensions of working memory and inhibitory control of the 48-72 month-old children and in total significantly vary by age?

3. According to the Childhood Executive Functioning Inventory, do the dimensions of working memory and inhibitory control of the 48-72 month-old children and in total significantly vary by the number of siblings?

4. According to the Childhood Executive Functioning Inventory, do the dimensions of working memory and inhibitory control of the 48-72 month-old children and in total significantly vary by the birth order?

When the data analysis is considered, it can be seen that the study requires the descriptive techniques as well as both inter-group comparisons and correlation analyses. Thus, the study has been designed according to the correlational survey model, one of the survey model types, in order to be able to identify the executive function skills of the children.. The correlational survey is a model which aims to identify the existence or level of differences between two or more variables (Kircaali İftar, 1998; Karasar, 2005). In this study, the variables examined relationally are working memory and inhibitory control, of the executive function skills, and the other variables such as gender, age, birth order and the number of siblings.

This study was carried out with the parents of the children attending various pre-school education institutions in Tokat province. The sample of the study was specified as 400 children 3-5 year-old picked by random sampling method from the pre-school education institutions and as their parents.Out of the 400 inventories handed out for the validity and reliability, 349 were returned. 9 of the returned scales were excluded from the data set due to incomplete filling, and 340 questionnaires were evaluated for the validity and reliability analyses.As for the inventory examined in terms of the different variables of the children, it was evaluated through 349 parents' forms.

The Personal Information Form and the Childhood Executive Functioning Inventory (Kayhan, 2010) (CHEXI) were used for the data collection. Developed by Thorell and Nyberg (2008) for the 4-7 year-old children and 
adapted to Turkish language and proved to be valid by Kayhan (2010), the Childhood Executive Functioning Inventory (CHEXI) was used, after having been analyzed its validity-reliability for the 48-72 month-old children by the researcher as the data collection tool.

The results of the study indicate that according to the childhood executive functioning form for parents, the working memory and inhibitory control skills of the 48-72 month-old children do not vary by gender, age and the number of siblings. In the related literature, there are studies suggesting different results on whether the working memory and inhibitory control vary by gender. For instance, (Blasiman and Was, 2018; Camerota, Willoughby, Kuhn, and Blair, 2018) a significant difference by gender was found out, i.e. the boys scored higher than the girls in both working memory and inhibitory control. According to another study (Hamamc1, 2020) carried out by the same scale, it was seen that the working memory and inhibitory control skills differed in favour of the girls. As for the teachers' assessment part of the form, it has been found out that inhibitory control differs in favour of the girls. On the other hand, Sağlam (2020) found out that the boys scored higher than the girls in working memory. In addition, Decker (2011) studied the relation between the working memory and academic skills of the children 4-6 years old, and concluded there was a significant relation between the verbal skills and auditory short-term memory, while no difference by gender was found.

However, in a study on the individuals at different ages, it was seen that the boys in the 13-15 age group displayed higher performance than the girls in 2 out of 3 tests assessing working memory (Gathercole et al., 2004). Still, further research is required to identify whether gender is a factor affecting working memory (Doğan,2011). The abovementioned studies concluded that there was not a significant difference by gender, confirming the outcomes of this study. Nevertheless, in some studies suggesting that the gender difference was not significant tried to explain this through the possible bias of the parents. It is stated that the stress and depression of parents may affect their perceptions towards the behaviours of their children (Joyner, Silver and Stavinoha, 2009; Silver, 2014); however, this study's conclusion that there is no difference by gender can be explained through parents' making the assessment more objectively. Another result of the study is that the scores of working memory and inhibitory control vary by the birth order 
significantly. It has been found that the difference between the first and middle children is significant in favour of the firstborn. As for the inhibitory control dimension, it has been seen that the difference between the middle and lastborn children is significant and in favour of the middle. These findings show parallelism with the findings of the longitudinal research by Holmgren, Molander and Nilsson (2008) on the effects of episodic memory and birth order. In this study, it was revealed that the memory performances of the firstborn children were better. It can be thought that the reason for the higher performance of the firstborn is the parents' focusing their care, concern and attention on them, and spending quality time without any interruption.

In other words, the memory perfomances of the firstborn may be better than of the others because the parents take care of them more and effectively.

In conclusion, it has been seen that according to the childhood executive functioning form for parents, the working memory and inhibitory control skills of the 48-72 month-old children do not vary by age and the number of siblings. However, it has been concluded that there is a significant difference in total in working memory and inhibitory control by the birth order. Between the first and middle children, this difference in the dimension of working memory has been found to be significant in favour of the firstborn.

In the dimension of inhibitory control, it has been seen that there is a significant difference between the middle and lastborn children in favour of the middle. As for the sum of the executive functions, it has been identified that there is a significant difference between the firstborn and lastborn children in favour of the previous one. In the light of these findings, it is suggested that the studies assessing and enhancing the working memory and inhibitory control skills, the most significant components of the executive functions of children, be carried out.

\section{Kaynakça / References}

Alloway, T. P., ve Alloway, R. G. (2010). Investigating the predictive roles of working memory and $\mathrm{IQ}$ in academic attainment. Journal of experimental childpsycholo$g y, 106(1), 20-29$.

Anderson, G., (2002). Assessment and development of executive function (EF) during childhood. Child Neuropsychology, 8(2), 71-82. 
Ardila, A., ve Surloff, C. (2004). Dysexecutive syndromes. Medlink Neurology: San Diego: Arbor Publishing Co.

Baddeley, A. (2006). Working memory: An overview Working memory and education içinde (p. 1-31). Elsevier.

Baddeley, A. (2012). Working memory: theories, models, and controversies. Annual review of psychology, 63, 1-29.

Baddeley, A. D., ve Hitch, G. (1974). Working memory.Psychology of learning and motivation içinde (Cilt. 8, s. 47-89). Elsevier.

Baddeley, A., Cocchini, G., Della Sala, S., Logie, R. H., ve Spinnler, H. (1999). Working memory and vigilance: Evidence from normal aging and Alzheimer's disease. Brain and cognition, 41(1), 87-108.

Barkley, R. A. (1997). Behavioral inhibition, sustained attention, and executive functions: constructing a unifying theory of ADHD. Psychological Bulletin, 121(1), 65.

Balota, D. A., ve Hambrick, D. Z. (2010). The relationship between working memory capacity and executive functioning: evidence for a common executive attention construct. Neuropsychology, 24(2), 222.

Baron, I. S. (2003). Neuropsychological evaluation of the child. Oxford University Press.

Blasiman, R. N., ve Was, C. A. (2018). Why is working memory performance unstable? A review of 21 factors. Europe's journal of psychology, 14(1), 188.

Brocki, K. C., ve Tillman, C. (2014). Mental set shifting in childhood: the role of working memory and inhibitory control. Infant and Child Development, 23(6), 588604.

Brown, W., Odom, S., McConnell, S., ve Rathel, J. (2008). Peer interaction interventions for preschool children with developmental difficulties. Social competence of young children: Risk, disability, and intervention, 2, 141-163.

Büyüköztürk, Ş., Çakmak-Kılıç, E., Akgün, Ö. E., Karadeniz, Ş., ve Demirel, F. (2014). Bilimsel araştırma yöntemleri. Ankara: Pegem Yayıncllk.

Camerota, M., Willoughby, M. T., Kuhn, L. J., ve Blair, C. B. (2018). The Childhood Executive Functioning Inventory (CHEXI): Factor structure, measurement invariance, and correlates in US preschoolers. Child Neuropsychology, 24(3), 322-337.

Carlson, S. M., ve Moses, L. J. (2001). Individual differences in inhibitory control and children's theory of mind. Child Development, 72(4), 1032-1053.

Cartwright, K. B. (2012). Insights from cognitive neuroscience: The importance of executive function for early reading development and education. Early Education \& Development, 23(1), 24-36. 
Catale, C., Lejeune, C., Merbah, S., ve Meulemans, T. (2013). French adaptation of the Childhood Executive Functioning Inventory (CHEXI): Confirmatory factor analysis in a sample of young French-speaking Belgian children. European Journal of Psychological Assessment, 29(2), 149.

Christoff, K., Ream, J. M., Geddes, L., ve Gabrieli, J. D. (2003). Evaluating selfgenerated information: anterior prefrontal contributions to human cognition. Behavioral neuroscience, 117(6), 1161.

Cooper-Kahn, J., ve Foster, M. (2013). Boosting executive skills in the classroom: A practical guide for educators: John Wiley \& Sons.

Corcoran, R. P., ve O'Flaherty, J. (2017). Executive function during teacher preparation. Teaching and Teacher Education, 63, 168-175.

Dehn, M. (2008). Working memory and academic learning: Assessment and intervention. Hoboken, NJ: John Wiley and Sons.

Dehn, M. (2010). Long-term memory problems in children and adolescens: Ssessment, intervention and effective instruction. Hoboken, NJ: John Wiley and Sons.

Diamond, A. (2002). Normal development of prefrontal cortex from birth to young adulthood: Cognitive functions, anatomy, and biochemistry. Principles of frontal lobe function, 466-503.

Diamond, A. (2013). Executive functions. Annual review of psychology, 64, 135-168.

Diamond, A., ve Goldman-Rakic, P. S. (1989). Comparison of human infants and rhesus monkeys on Piaget's AB task: evidence for dependence on dorsolateral prefrontal cortex. Experimental Brain Research, 74(1), 24-40.

Doğan, M. (2011). Çocuklarda çalışma belleği, akademik öğrenme ve öğrenme yetersizlikleri. Türk Psikoloji Yazılan, 14(27), 48-65.

Ertuğrul, Z. (2011). Zihin kuramı, dil ve çalışma belleği arasındaki gelişimsel bağlantılar. Yüksek lisans tezi, İstanbul Üniversitesi.

Garon, N., Bryson, S. E., ve Smith, I. M. (2008). Executive function in preschoolers: a review using an integrative framework. Psychological Bulletin, 134(1), 31.

Gathercole, S. E., Pickering, S. J., Ambridge, B., ve Wearing, H. (2004a). The structure of working memory from 4 to 15 years of age. Developmental psychology, 40(2), 177.

Gathercole, S. E., Pickering, S. J., Knight, C., ve Stegmann, Z. (2004b). Working memory skills and educational attainment: Evidence from national curriculum assessments at 7 and 14 years of age. Applied Cognitive Psychology, 18(1), 1-16. 
Gathercole, S.E. ve Dunning, D. (2009). Adaptive training leads to sustained enhancement of poor working memory in children. Developmental Science, 12(4), 9-15.

Goldstein, S., Naglieri, J. A., Princiotta, D., ve Otero, T. M. (2014). Introduction: A history of executive functioning as a theoretical and clinical construct Handbook of executive functioning (pp. 3-12): Springer.

Groen, L. (2015). De invloed van gezinsfactoren op de ontwikkeling van executieve functies bij kinderen in de bovenbouw van het basisonderwijs. Master's thesis. Education and Child Studies.

Hamamc, B. (2020). Okul öncesi dönem çocuklarnnn yürütücü işlev becerilerinin değerlendirilmesi. Yayınlanmamış yüksek lisans tezi, Marmara Üniversitesi.

Harris, K. I. (2016). Supporting executive function skills in early childhood: Using a peer buddy approach for community, confidence, and citizenship. Journal of Education and Training, 3(1), 158-175.

Holmgren, S., Molander, B., ve Nilsson, L. (2008). Episodic memory in adult age and effects of sibship size. Journal of Adult Development, 14(37), 37-46.

Huizinga, M., Dolan, C. V., ve van der Molen, M. W. (2006). Age related change in executive function: developmental trends and a latent variables analysis. Neuropsychologia, 44, 2017-2036.

İvrendi, A. (2020). Okula hazır bulunuşluk ve yürütücü işlev performansları arasındaki ilişki. Erken Çocukluk Çalışmaları Dergisi, 4(2), 66-87.

Joyner, K. B., Silver, C. H., ve Stavinoha, P. L. (2009). Relationship between parenting stress and ratings of executive functioning in children with $\mathrm{ADHD}$. Journal of Psychoeducational Assessment, 27, 452-464.

Kayhan, E. (2010). A validation study for the childhood executive functioning inventory: Behavioral correlates of executive functioning. Yayımlanmamış yüksek lisans tezi. Boğaziçi Üniversitesi.

Lehto, J., Juujarvi, P., Kooistra, L., ve Pulkkinen, L. (2003). Dimensions of executive functioning: Evidence from children. British Journal of Developmental Psycholo$g y, 21,59-80$.

Logan, G. D., Schachar, R. J., ve Tannock, R. (1997). Impulsivity and inhibitory control. Psychological Science, 8(1), 60-64.

McCabe, D. P., Roediger III, H. L., McDaniel, M. McClelland, M. M., Cameron, C. E., Connor, C. M., Farris, C. L., Jewkes, A. M., ve Morrison, F. J. (2007a). Links between behavioral regulation and preschoolers' literacy, vocabulary,and math skills. Developmental psychology, 43(4), 947.

Meltzer, L. (2010). Promoting executive function in the classroom: Guilford Press. 
Meltzer, L. (2018). Executive function in education: From theory to practice: Guilford Publications.

Öğütcen, A. (2020). Okul öncesi dönem çocuklarmnın yürütücü işlev becerileri ve geometrik şekil algılarının incelenmesi. Yayınlanmamış yüksek lisans tezi, Hacettepe Üniversitesi.

Pennington ve Ozonoff, S. (1996). Executive functions and developmental psychopathology. Journal of Child Psychology and Psychiatry, 37(1), 51-87.

Sağlam, C. (2020). Okul öncesi dönemde çalışma belleği ve erkenokuryazarlık becerilerinin incelenmesi. Yayınlanmamış doktora tezi. Karabük Üniversitesi.

Silver, C. H. (2014). Sources of data about children's executive functioning: Review and commentary. Child Neuropsychology, 20, 1-13.

St. Clair-Thompson, H. L., ve Gathercole, S. E. (2006). Executive functions and achievements on national curriculum tests: Shifting, updating, inhibition, and working memory. Quarterly Journal of Experimental Psychology, 59, 745759.

Storbeck, J., ve Maswood, R. (2016). Happiness increases verbal and spatial working memory capacity where sadness does not: emotion, working memory and executive control. Cognition and Emotion, 30(5), 925-938.

Swanson, R. A. (2001). Human resource development and its underlying theory. Human Resource Development International, 4(3), 299-312.

Thorell, L. B. ve Nyberg, L. (2008). The childhood executive functioning inventory (CHEXI): A new rating instrument for parents and teachers. Developmental Neuropsychology, 33(4), 536-552.

Thorell, L. B., ve Catale, C. (2014). The assessment of executive functioning using the Childhood Executive Functioning Inventory (CHEXI) Handbook of executive functioning (pp. 359-366): Springer.

Tuncer, N. (2018). Okul öncesi çocuklarının yürütücü işlevlerinin gelişimini desteklemeye yönelik öğretmen eğitim programının etkililiğinin incelenmesi. Yayınlanmamış doktora tezi, Gazi Üniversitesi.

Tuncer, N. (2019). Okul öncesi öğretmenlerinin çocukların yürütücü işlevlerini destekleyen stratejileri kullanma yeterlilikleri ölçeğinin geliştirilmesi. Mehmet Akif Ersoy Üniversitesi Ë̆itim Fakültesi Dergisi, 52, 212-236.

Vitiello, V. E., ve Greenfield, D. B. (2017). Executive functions and approaches to learning in predicting school readiness. Journal of Applied Developmental Psychology, 53, 1-9. 
Welsh, J. A., Nix, R. L., Blair, C., Bierman, K. L., ve Nelson, K. E. (2010). The development of cognitive skills and gains in academic school readiness for children from low-income families. Journal of Educational Psychology, 102(1), 43.

Zelazo, P. D., Müller, U., Frye, D., ve Marcovitch, S. (2003). The development of executive function in early childhood: I. The development of executive function. Monographs of the society for research in child development.

Zelazo, P. D., Müller, U., Frye, D., Marcovitch, S., Argitis, G., Boseovski, J., Sutherland, A. (2003). The development of executive function in early childhood. Monographs of the society for research in child development, i-151.

\section{Kaynakça Bilgisi / Citation Information}

Tuncer, N. (2021). Çocukluk dönemi yürütücü işlev envanteri-ebeveyn formu'nun 48-72 aylık çocuklara uyarlanması ve bazı değişkenler açısından yordanma gücünün incelenmesi. OPUS-Uluslararası Toplum Araştırmaları Dergisi, 17(35), 2052-2081. DOI: 10.26466/opus.832602 